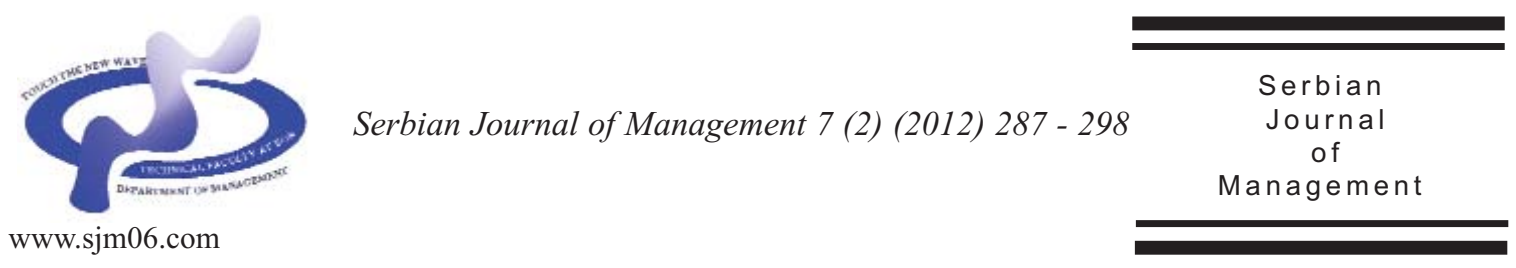

\title{
EVALUATING THE LIFE CYCLE COSTS OF PLANT ASSETS - A MULTIDIMENSIONAL VIEW -
}

\author{
Markus Gram* and Werner E. Schroeder \\ Chair of Economic and Business Management, Montanuniversitaet Leoben, \\ Peter Tunner Straße 25-27, A-8700 Leoben, Austria
}

(Received 12 May 2012; accepted 29 August 2012)

\begin{abstract}
This paper shows the results of the task group "Asset life cycle management" of the Austrian Scientific Maintenance and Asset Management Association (ÖVIA). One purpose of the research activities is to create a generic life cycle model for physical assets which includes all costs in every phase of the asset life cycle. The first step is a literature review determining the most established life cycle cost models. This is the input for discussing the completeness of such frameworks with the participating industrial companies. A general model is deducted from existing approaches and the determined costs are evaluated with respect to priority and practical relevance. The result of the evaluation shows which costs are taken into account for investment decisions. Another outcome of the study is the verification of importance of the proposed costs for industrial companies, especially for the process industry. The derived life cycle cost framework is the basis for developing a calculation tool and subsequently, for further research in the flied of uncertainty-based methodologies for life cycle cost analyzing of physical plant assets.
\end{abstract}

Keywords: Life cycle costs, Maintenance, Asset management, Cost evaluation, Investment decisions

\section{INTRODUCTION}

The increasing significance of indirect costs in investment decisions has moved the total cost contemplation into the focus instead of only viewing on acquisition costs.
This trend will be reinforced by rising energy and material costs. Due to this development companies as well as industrial associations have started to deal with life cycle models as part of a strategic cost management. The aim of these models is to provide a complete and

\footnotetext{
* Corresponding author: markus.gram@unileoben.ac.at
}

DOI: $10.5937 /$ sjm 7-2545 
accurate registration of all connected costs over the investments life cycle. The increasing proliferation of these models is associated with a limited scientific contemplation (Gleissdörfer, Gleich \& Wald, 2009). Basically two trends can be distinguished. On the one hand specific calculation models are pointed out. These frameworks are based on case studies or are developed for particular industrial sectors. On the other hand guidelines are shown to support the step by step development of a companyspecific model. In general standard models and standardized structures for the calculation of cost categories and cost drivers are missing. The need for research is therefore in the development of standard models with appropriate cost categories and cost drivers. This could be the basis for industry and companyspecific adjustments.

So the first target of this paper is to determine the most established life cycle cost (LCC) models by reviewing literature. This is the input for discussing the completeness and practical relevance of such frameworks. Then a standardized model is deducted from existing approaches. Before discussing the most established LCC models the next sections provide the background and a brief introduction into plant asset management as well as into the asset life cycle.

\section{PLANT ASSET MANAGEMENT}

Plant asset management is defined as a strategic, integrated set of comprehensive processes (financial, management, engineering, operation and maintenance) to gain greatest lifetime effectiveness, utilization and return from physical assets (production and operation equipment and structures) (Mitchell \& Carlson, 2001). To gain even greater value, the asset management process should extend from design, procurement and installation through operation, maintenance and retirement, i.e. over the complete life cycle. Plant asset management as a corporate activity focuses on the tangible fixed assets (plants/manufacturing equipment). (Nebl \& Prüß, 2005) Plant asset management contains activities and as well as decision making and covers the asset life cycle phases of investment (including asset design and asset provision), operations and maintenance (including improvement and administration) and decommissioning of tangible fixed assets (see figure 1). The fields of activities as well as the aims of asset management are discussed as followed.

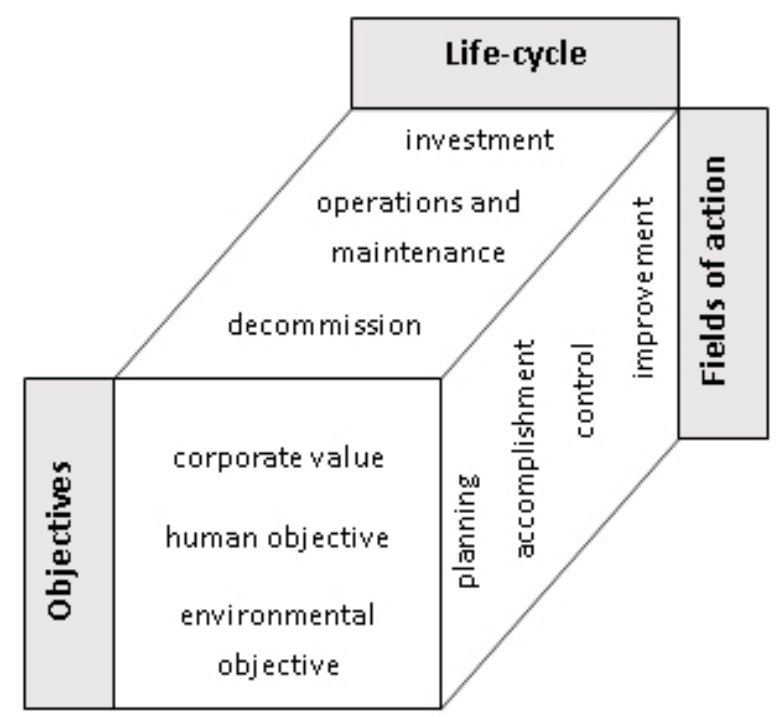

Figure 1. Plant asset management: objectives, life cycle and fields of action based on (Männel, 1988)

Asset management activities have to be designed, implemented and controlled through appropriate decision and management processes. Fields of action include planning, accomplishment, control 
and improvement of all activities related to plant asset management, the activities are supported with information systems (Campbell \& Jardine, 2001). Derived from the main objectives of a company (particularly the longterm increase of the corporate value), asset management subgoals have to be formulated that make a significant contribution to the operational and sustainability performance of a company possible. In sequence of the asset life cycle (investment, operations and maintenance, decommission) it requires an aligned asset management framework, which considers the operational human needs (human objective) and the environmental requirements (environmental objective).

\section{ASSET LIFE CYCLE}

The life cycle of a plant asset characterizes the economic life time of the asset in a company. The asset life cycle consists of three phases similar to a product life cycle in terms of consumer goods and it begins with the supply of the asset by an investment, the operations and ends with their decommission. The first phase of the asset life cycle is the investment phase. Based on investment needs and investment decisions the projection, purchasing, installation and commissioning of the investment object takes place. As part of the investment an asset is provided and installed. The aim of the provision is either the creation of additional production capacity or the replacement of worn or overage manufacturing resources. Also rationalization objectives can be realized by investing in new technologies. During the useful life the asset produces goods and services, but at the same time the given using stock of the asset decreases, i.e. the productivity of the asset is declining. Assuring the performance of the assets is the main task of maintenance. All activities which serve to perpetuation, reestablishment or improvement of the using stock are part of the plant maintenance. The tasks of maintenance are divided into inspection, attendance and repair. In the context of maintenance the tasks also have to include simultaneously some improvement and modernization activities at the using stock (DIN 31051, 2011).

The phase of asset operations and maintenance is followed by the phase of disinvestment. Here the decommission takes place, i.e. the asset is dissolved away from the operating process. The need for disinvestment results not only in technical (abrasion of the assets), but also in economic reasons (changing demands, ensuring competitiveness, financing).

\section{LIFE CYCLE COSTING}

The decentralized arrangement of the individual business areas (investment, operations and maintenance, decommission) often leads to functional and inconsistent goals. Thus, existing correlations in the various decision areas of plant asset management are not optimally aligned. The challenge in managing the entire asset life cycle effectively lies in the fact that cost are isolated and addressed in a fragment way through the various stages. During the investment stage the emphasis is on implementing a technology with the boundaries of the approved budget and prescribed time frame, while ensuring that the facility conforms to the technical specifications (Schuman \& Brent, 2005). 
The primary drivers for the utilization phase (operations and maintenance) are the associated costs of product distribution, spare parts and inventory, maintenance, training, etc. The present plant asset management especially in the process industry has focused on maintenance management models (AmadiEchendu, 2004) i.e. total productive maintenance (TPM) (Ahuja \& Khamba, 2008), reliability centered maintenance (RCM) (Campbell, 1995 or Selvik \& Aven, 2011), and risk based maintenance (RBM) (Selvik \& Aven, 2011). Some advantages and disadvantages of these concepts are discussed by (Waeyenberg \& Pintelon, 2002).

A major disadvantage of applying only these models is that an estimate 65 per cent of an asset's LCC are fixed during early phases of the life cycle (Barringer, 1997). Potential cost benefits are consequently lost due to shortterm cost drivers during the acquisition phase in the asset's life cycle. The concept of terotechnology has traditionally attempted to address this deficiency, which is a combination of management, financial, engineering and other practices applied to physical assets in pursuit of economic LCC (AmadiEchendu, 2004). To enhance and sustain the value of physical assets, plant asset management requires a paradigm shift beyond normal cost principles of maintenance.

To achieve the integration of all subsystems with the aim of minimizing the total cost of an investment over its entire life cycle provides the framework of LCC. Life cycle costs are the sum of all necessary expenses from acquisition to disposal of a machine or system. LCC is focusing on the cost analysis of alternative investment decisions. Thereby a clear definition of the task, a specification of conditions and factors as well as similarly outputs have to be set to enable the comparability of the performances.

In addition to the LCC approach the concept of total cost of ownership (TCO) is also used frequently in literature. Both, LCC and TCO are instruments of the strategic cost management to analyze the total costs of a system. However, a clear separation of these two approaches is often missing in the technical literature. A distinction can be made due to the involvement of transactions costs. In LCC frameworks transaction costs are only partially or not taken into consideration, while TCO takes transaction costs along the supply chain into account. Since this paper focuses on systems with a long useful life, which are not supplied regularly recurring, it is not appropriate to take transaction costs into account. In a literature review to derive a general standardized life cycle model a number of ten LCC approaches are identified (see table $1)$.

To deduct a standardized and generic LCC model from this existing approaches, especially for physical plant assets we focused on frameworks and guidelines of engineering standards and industrial associations (VDMA 34160, VDI 2884 and DIN EN 6030033) for further analysis. Other frameworks are too specific (food, traffic, railway) or represent only guidelines without explicit cost categories.

The selected three frameworks (table 2) are not discussed in detail. Basically it can be said, no approach satisfies the claim of completeness. However, each framework or guideline can be expanded for the calculation of LCC in the case of a specific application. To remedy the deficiency of a missing completeness an own LCC model is defined. Goal is to identify and define the holistic 
Table 1. Overview of existing LCC approaches (according to Gleissdörfer et al., 2009)

\begin{tabular}{|c|c|c|c|c|c|c|}
\hline \multirow[t]{2}{*}{ Model } & \multirow[t]{2}{*}{ Industrial sector } & \multicolumn{5}{|c|}{ Quality criteria } \\
\hline & & 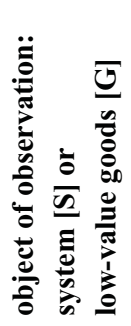 & 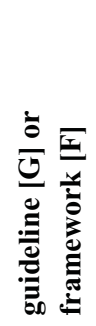 & 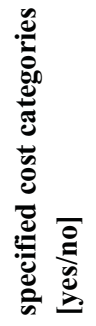 & 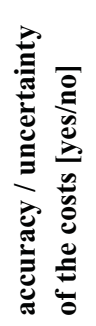 & 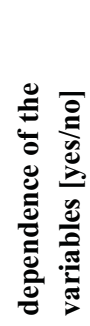 \\
\hline $\begin{array}{l}\text { VDMA } 34160 \text { (VDMA } \\
34160,2007)\end{array}$ & engineering & $\mathrm{S}$ & $\mathrm{F}$ & $\mathrm{Y}$ & $\mathrm{N}$ & $\mathrm{N}$ \\
\hline NAFEM (NAFEM, 2006) & food equipment & $\mathrm{S}$ & $\mathrm{F}$ & $\mathrm{Y}$ & $\mathrm{N}$ & $\mathrm{N}$ \\
\hline Kaufmann (Kaufmann, 1969) & food & $\mathrm{S}$ & $\mathrm{F}$ & $\mathrm{Y}$ & $\mathrm{N}$ & $\mathrm{N}$ \\
\hline VDI 2884 (VDI 2884, 2008) & plant assets & $\mathrm{S}$ & $\mathrm{F}$ & $\mathrm{Y}$ & $\mathrm{N}$ & $\mathrm{N}$ \\
\hline VDV 2315 (VDV 2315, xxx) & traffic & $\mathrm{S}$ & $\mathrm{F}$ & $\mathrm{Y}$ & $\mathrm{N}$ & $\mathrm{N}$ \\
\hline $\begin{array}{l}\text { DIN EN 60300-3-3 (DIN EN } \\
60300,2004)\end{array}$ & generic & $\mathrm{S} / \mathrm{G}$ & $\mathrm{G} / \mathrm{F}$ & $\mathrm{Y}$ & $\mathrm{Y}$ & $\mathrm{N}$ \\
\hline $\begin{array}{l}\text { UNILIFE LCC (UNIFE, } \\
\text { 1997) }\end{array}$ & railway & $\mathrm{S}$ & $\mathrm{F}$ & $\mathrm{Y}$ & $\mathrm{Y}$ & $\mathrm{N}$ \\
\hline Zehbold (Zehbold, 1996) & generic & $\mathrm{G}$ & $\mathrm{G}$ & $\mathrm{N}$ & $\mathrm{Y}$ & $\mathrm{Y}$ \\
\hline Riezler (Riezler, 1996) & generic & $\mathrm{S} / \mathrm{G}$ & $\mathrm{G}$ & $\mathrm{N}$ & $\mathrm{Y}$ & $\mathrm{Y}$ \\
\hline Kemminer (Kemminer, 1999) & generic & $\mathrm{G}$ & $\mathrm{G}$ & $\mathrm{N}$ & $\mathrm{Y}$ & $\mathrm{Y}$ \\
\hline
\end{tabular}

Table 2. Selected LCC frameworks

\begin{tabular}{|c|c|c|}
\hline Designation & Concept & Editor \\
\hline $\begin{array}{l}\text { VDMA 34160: Forecasting model for } \\
\text { lifecycle costs of machines and plants }\end{array}$ & $\begin{array}{l}\text { Forecasting model for } \\
\text { calculating LCC of machinery, } \\
\text { equipment, and components } \\
\text { inclusive an excel based } \\
\text { calculation tool }\end{array}$ & $\begin{array}{l}\text { German Engineering } \\
\text { Federation (VDMA) }\end{array}$ \\
\hline $\begin{array}{l}\text { Policy VDI 2008: Procurement, operation } \\
\text { and maintenance of production equipment } \\
\text { using LCC }\end{array}$ & $\begin{array}{l}\text { Preconfigured and extensible } \\
\text { policy to calculate LCC of plant } \\
\text { assets / production equipment }\end{array}$ & $\begin{array}{l}\text { Association of German } \\
\text { Engineers (VDI) }\end{array}$ \\
\hline $\begin{array}{l}\text { DIN EN 60300-3-3 Dependability } \\
\text { management - Part 3-3: Application guide - } \\
\text { Life cycle costing (IEC 60300-3-3:2004); } \\
\text { German version EN 60300-3-3:2004 }\end{array}$ & $\begin{array}{l}\text { General instructions for } \\
\text { conducting an analysis of LCC, } \\
\text { including the development of } \\
\text { the model }\end{array}$ & $\begin{array}{l}\text { German Institute for } \\
\text { Standardization (DIN) }\end{array}$ \\
\hline
\end{tabular}

nature of possible costs in all phases of a system's life cycle. In order to perform the detailed costs for the industry, an assessment of cost priority was conducted take on use of companies from the task group, especially from the process industry.

\section{EVALUATION PROCESS OF THE LIFE CYCLE COST MODEL}

The base of the evaluation process is to define the cost elements of the model. In the literature established asset life models described in table 2 are used to identify the major costs inside the three phases of the life cycle. Figure 2 shows the expiration of the evaluation process. 


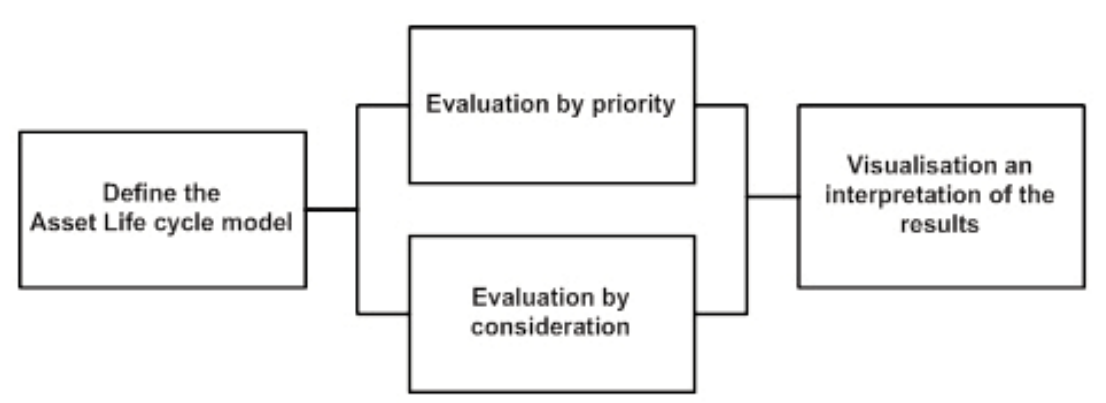

Figure 2. Evaluation process

First, the main structure of the created model is explained. The next step shows and explains the evaluation of the proposed model by the participating companies within the workgroup. For further development of the asset life cycle model the result show which cost elements are important for the participating industries. If it is clear what the focus of interest is, the important cost elements can investigated more detailed.

\subsection{Defining the asset life cycle model}

The general life cycle of goods pretend a framework to develop a general cost model. At section above, the basic framing includes three phases (equipment acquisition, operational and decommission). The stages of the life cycle can even be subdivided in subgroups. These are activities which are needed to manage the equipment in every phase. Every activity causes different costs which are stated. To describe the main and the substructure a numeration helps to identify the given cost elements. Table 3 describes the numeric logic of the model.
The numeration is partitioned in three parts. The first Number (AA) stands for the life cycle phase, in which the cost elements occur. Next part (BB) identifies the subgroups. Subgroups are specific activities inside the main phases. The last component (CC) is the number of the cost element per subgroup. With this numeration each cost element can be identified. Another advantage is the expandability of the model.

\subsection{Companies evaluation results and costs matching with the considered life cycle models}

Once the main structure of the model is defined, the evaluation is carried out in two stages. First, every company of the task group gets a questionnaire to rank the cost elements by importance. This means which elements are of interest for the companies to get recorded. The ranking is summarized in a five point Likert scale ( 5 = "very important" or "of high interest" and $1=$ "totally negligible"). In the final result the value per cost element is the average of the returning

Table 3. Structure of the model

\begin{tabular}{lll}
\hline Numeration & Description & Examples \\
\hline A.B.C.D & numbering structure & $1.1 .1,1.2 .1,1.3 .2, \ldots$ \\
\hline A & main life cycle phase & equipment acquisition, operational and decommission \\
\hline B & subgroups of the phases & $\begin{array}{l}\text { research and development, first time operation, } \\
\text { maintenance, operations, decommission }\end{array}$ \\
\hline C, D & cost elements & tools, energy, testing, ... \\
\hline
\end{tabular}


ranking. The next evaluation step is to clarify which cost elements are already recorded. The companies get a questionnaire to check the relevant cost elements. The following tables 46 show the final result of the evaluation. Additional the consideration of the cost elements in the existing asset life cycle models is marked. better identification.

Every point in this portfolio represents a cost element in the model and the numbers indicates the costs. The cost elements are widely dispersed in the portfolio. Nevertheless it is striking that most of the cost elements of the utilization phase are positioned in quadrant 2 . In this part of the

Table 4. Description and evaluation results of the equipment acquisition phase

\begin{tabular}{|c|c|c|c|c|c|c|}
\hline \multirow[b]{2}{*}{ Nr. } & \multirow[b]{2}{*}{ description } & \multirow{2}{*}{$\begin{array}{l}\text { importance } \\
\text { by the companies }\end{array}$} & \multicolumn{4}{|c|}{ considered } \\
\hline & & & 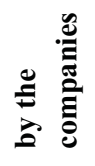 & $\begin{array}{l}\stackrel{+}{\infty} \\
\stackrel{\infty}{+} \\
\overline{1}\end{array}$ & 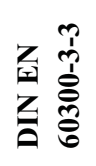 & 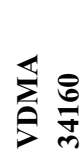 \\
\hline 1.1 & research and development & & & & & \\
\hline 1.1 .1 & data sourcing & 2,67 & 0 & & $\mathrm{X}$ & \\
\hline 1.1 .2 & research and development process & 3 & 2 & & $\mathrm{X}$ & \\
\hline 1.1 .3 & $\begin{array}{l}\text { development of maintenance strategies } \\
\text { and maintenance plans }\end{array}$ & 3,25 & 0 & & $X$ & \\
\hline 1.1 .4 & program management and administration & 2 & 0 & & $\mathrm{X}$ & \\
\hline 1.1 .5 & project planning, concept development & 3,75 & 1 & $X$ & $\mathrm{X}$ & \\
\hline 1.1 .6 & calculation and engineering & 3,75 & 2 & & $\mathrm{X}$ & \\
\hline 1.1 .7 & testing & 3,67 & 0 & $\mathrm{X}$ & $\mathrm{X}$ & \\
\hline 1.1 .8 & construction and design & 4,25 & 2 & & $\mathrm{X}$ & \\
\hline 1.2 & first time operation & & & & & \\
\hline 1.2 .1 & logistic & 2,5 & 0 & & $\mathrm{X}$ & $\mathrm{X}$ \\
\hline 1.2 .2 & original spare parts & 3 & 3 & $\mathrm{X}$ & $\mathrm{X}$ & $\mathrm{X}$ \\
\hline 1.2 .3 & acquisition of modern tools & 2,25 & 3 & $\mathrm{X}$ & $\mathrm{X}$ & $\mathrm{X}$ \\
\hline 1.2 .4 & assembly & 4 & 3 & $\mathrm{X}$ & $\mathrm{X}$ & \\
\hline 1.2 .5 & training & 3,5 & 2 & $\mathrm{X}$ & $\mathrm{X}$ & $\mathrm{X}$ \\
\hline 1.2 .6 & system integration & 4 & 0 & $\mathrm{X}$ & $\mathrm{X}$ & $\mathrm{X}$ \\
\hline 1.2 .7 & $\begin{array}{l}\text { additional equipment and extension of a } \\
\text { plant }\end{array}$ & 3,5 & 2 & $\mathrm{X}$ & & $\mathrm{X}$ \\
\hline 1.2 .8 & ramp-up & 4,25 & 1 & $\mathrm{X}$ & & \\
\hline 1.2 .9 & test phase & 4,5 & 0 & $\mathrm{X}$ & & \\
\hline 1.2 .10 & $\begin{array}{l}\text { infrastructure reconstruction at the } \\
\text { workshop }\end{array}$ & 4,25 & 3 & $\mathrm{X}$ & & $\mathrm{X}$ \\
\hline 1.2 .11 & $\begin{array}{l}\text { spare parts catalog and spare parts } \\
\text { procurement by definition }\end{array}$ & 4 & 1 & $X$ & $X$ & $X$ \\
\hline
\end{tabular}

\subsection{Portfolio of the evaluation results}

To get a better overview and to see which cost elements are relevant for further processing a portfolio is given in Figure 3. The axes represent the consideration and the importance by the companies. The portfolio is divided into four quadrants to cluster the costs. The subgroups are color coded for portfolio is not a need for a detailed recording of the costs given. The companies have the feasibility to collect the data for further use. The other cost elements have no significant concentration in one of the quadrates. It must be checked whether the data can be recorded. For this analysis Quadrant 4 is the most important cluster. The costs in this section are very important for 
Table 5. Description and evaluation results of the operational phase

\begin{tabular}{|c|c|c|c|c|c|c|}
\hline \multirow[b]{2}{*}{ Nr. } & \multirow[b]{2}{*}{ description } & \multirow{2}{*}{ 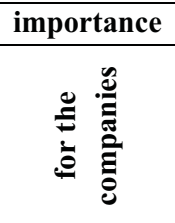 } & \multicolumn{4}{|c|}{ considered } \\
\hline & & & 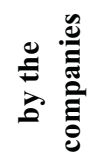 & 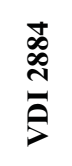 & 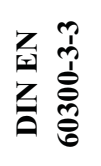 & $\sum_{i}^{\sharp 8}$ \\
\hline 2.1 & maintenance & & & & & \\
\hline 2.1 .1 & transportation of equipment parts & 2,25 & 1 & & & \\
\hline 2.1 .2 & system / equipment changes & 3,75 & 2 & & & \\
\hline 2.1 .3 & documentation & 3,5 & 1 & & $\mathrm{X}$ & \\
\hline 2.1 .4 & labor, materials and administration & 4,25 & 1 & $\mathrm{X}$ & $\mathrm{X}$ & $X$ \\
\hline 2.1.4.1 & tools & 3,25 & 2 & $\mathrm{X}$ & $\mathrm{X}$ & $\mathrm{X}$ \\
\hline 2.1 .4 .2 & IT System & 4 & 1 & & $\mathrm{X}$ & $\mathrm{X}$ \\
\hline 2.1.4.3 & IH personnel & 4,25 & 3 & & $\mathrm{X}$ & $\mathrm{X}$ \\
\hline 2.1.4.4 & Spare parts & 5 & 2 & $\mathrm{X}$ & $\mathrm{X}$ & $\mathrm{X}$ \\
\hline 2.1 .5 & replacement and renewal & 4,75 & 2 & $\mathrm{X}$ & $\mathrm{X}$ & $\mathrm{X}$ \\
\hline 2.2 & operations & & & & & \\
\hline 2.2 .1 & ongoing training for maintenance and operation & & & & & \\
\hline 2.2 .1 .1 & technical training & 3,5 & 2 & $\mathrm{X}$ & $\mathrm{X}$ & \\
\hline 2.2 .1 .2 & methodological training & 3,5 & 0 & $\mathrm{X}$ & $\mathrm{X}$ & \\
\hline 2.2 .2 & Energy and asset utilization & & & & & \\
\hline 2.2 .2 .1 & industrial water & 5 & 3 & $\mathrm{X}$ & & $\mathrm{X}$ \\
\hline 2.2.2.2 & compressed air & 4,75 & 3 & $\mathrm{X}$ & & $\mathrm{X}$ \\
\hline 2.2 .2 .3 & energy & 5 & 3 & $\mathrm{X}$ & $\mathrm{X}$ & $\mathrm{X}$ \\
\hline 2.2 .3 & collection and analysis of technical data (IT) & & & & & \\
\hline 2.2 .3 .1 & sensors & 2,75 & 0 & & $\mathrm{X}$ & $\mathrm{X}$ \\
\hline 2.2 .3 .2 & personnel for interpretation & 3,25 & 2 & & $\mathrm{X}$ & $\mathrm{X}$ \\
\hline 2.2 .3 .3 & ERP System & 4,67 & 2 & & $\mathrm{X}$ & $\mathrm{X}$ \\
\hline 2.2 .4 & losses & & & & & \\
\hline 2.2 .4 .1 & nonproductive time & 3,75 & 2 & $\mathrm{X}$ & $\mathrm{X}$ & $\mathrm{X}$ \\
\hline 2.2 .4 .2 & maintenance and care times & 4,5 & 3 & $\mathrm{X}$ & $\mathrm{X}$ & $\mathrm{X}$ \\
\hline 2.2 .4 .3 & set-up times & 4,25 & 2 & $\mathrm{X}$ & $\mathrm{X}$ & $\mathrm{X}$ \\
\hline 2.2 .4 .4 & downtimes & 4,25 & 3 & $\mathrm{X}$ & $\mathrm{X}$ & $\mathrm{X}$ \\
\hline 2.2 .5 & input factors & & & & & \\
\hline 2.2 .5 .1 & personnel & 3,75 & 2 & & $\mathrm{X}$ & $\mathrm{X}$ \\
\hline 2.2 .5 .2 & administration & 3,75 & 1 & & $\mathrm{X}$ & $\mathrm{X}$ \\
\hline 2.2 .5 .3 & direct service personnel & 3,75 & 2 & & $\mathrm{X}$ & $\mathrm{X}$ \\
\hline 2.2 .5 .4 & operating materials & 4,5 & 3 & & $\mathrm{X}$ & $\mathrm{X}$ \\
\hline
\end{tabular}

\section{Table 6. Description and evaluation results of the retirement and decommission phase}

\begin{tabular}{|c|c|c|c|c|c|c|}
\hline Nr. & description & importance & & consi & ered & \\
\hline & & 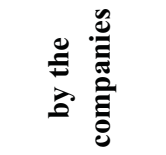 & 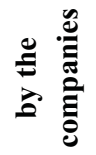 & 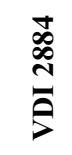 & 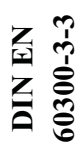 & 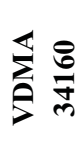 \\
\hline 3.1 & decommission & & & & & \\
\hline 3.1 .1 & legal requirements & 3 & 1 & & & \\
\hline 3.1 .2 & demolition and scrapping & 2,75 & 2 & $\mathrm{X}$ & $X$ & $\mathrm{X}$ \\
\hline 3.1 .3 & redevelopment & 2,75 & 2 & $\mathrm{X}$ & & $\mathrm{X}$ \\
\hline 3.1 .4 & disposal of material and supplies & 2,75 & 2 & $\mathrm{X}$ & $\mathrm{X}$ & $\mathrm{X}$ \\
\hline
\end{tabular}




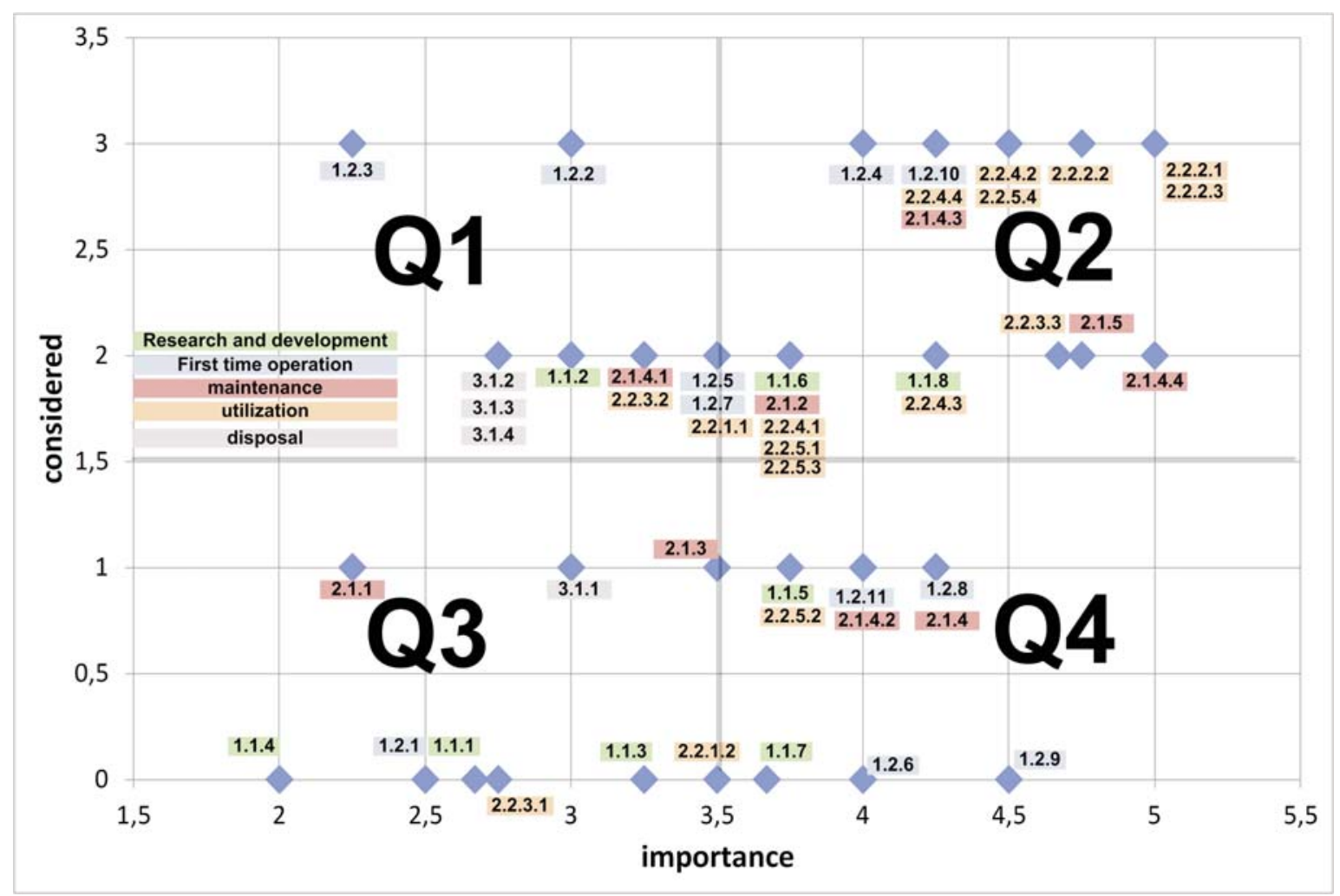

Figure 3. Portfolio of the evaluation results

the companies but almost not considered in preventive activities like 1.2.11, 1.2 .8 or the controlling system. The most significant 1.2 .9 , etc. are not considered by the elements are presented in table 7. companies. This lack of detection has a

Table 7. Cost elements of interest (quadrant 4)

\begin{tabular}{llrr}
\hline Nr. & description & importance & considered \\
\hline 1.1 .7 & testing & 3.67 & 0 \\
\hline 1.1 .5 & project planning, concept development & 3,75 & 1 \\
\hline 1.2 .6 & system integration & 4 & 0 \\
\hline 1.2 .8 & ramp-up & 4.25 & 1 \\
\hline 1.2 .9 & test phase & 4.5 & 0 \\
\hline & spare parts catalog and spare parts & & \\
1.2 .11 & procurement by definition & 4 & 1 \\
\hline 2.1 .3 & documentation & 3.5 & 1 \\
\hline 2.1 .4 & labor, materials and administration & 4.25 & 1 \\
\hline 2.1 .4 .2 & IT system & 4 & 1 \\
\hline 2.2 .1 .2 & methodological training & 3.5 & 0 \\
\hline 2.2 .5 .2 & administration & 3.75 & 1 \\
\hline
\end{tabular}

The result shows that in the equipment significant impact on the later phases of the acquisition phase of the life cycle some life cycle. Furthermore, cost elements inside 
the operational phase are not recorded from the participating companies, but these are obviously important for the full costs. These elements should included to the controlling system of the companies and be considered in the lifecycle viewing.

\section{DISCUSSION AND FURTHER RESEARCH}

Further research is needed for developing a calculation tool as well as to extend the model such that it can be filtered according to different types of costs. So it should be possible to look separately at e.g. logistics costs, training costs or energy costs over the entire life cycle of a plant asset in order to benefit from an even better basis for future investment decisions. Figure 4 shows the concept of the life cycle cost decision tool.
The main aim of this approach is to initiate a knowledge transfer between two investment periods. Additional to the cost structure, several tools support this lesson learned process to achieve an improvement of the physical plant assets. Maintainability checklist, maintenance oriented design and a TPM certification are only some examples for tools to achieve this.

\section{CONCLUSION}

As a basis for considering LCC, it is imperative to formulate a cost model. Existing frameworks and guidelines (according to VDMA 34160 or VDI 2884) represent the starting position of considerations. In terms of their completeness, practicality and image quality these models, however, have weaknesses.

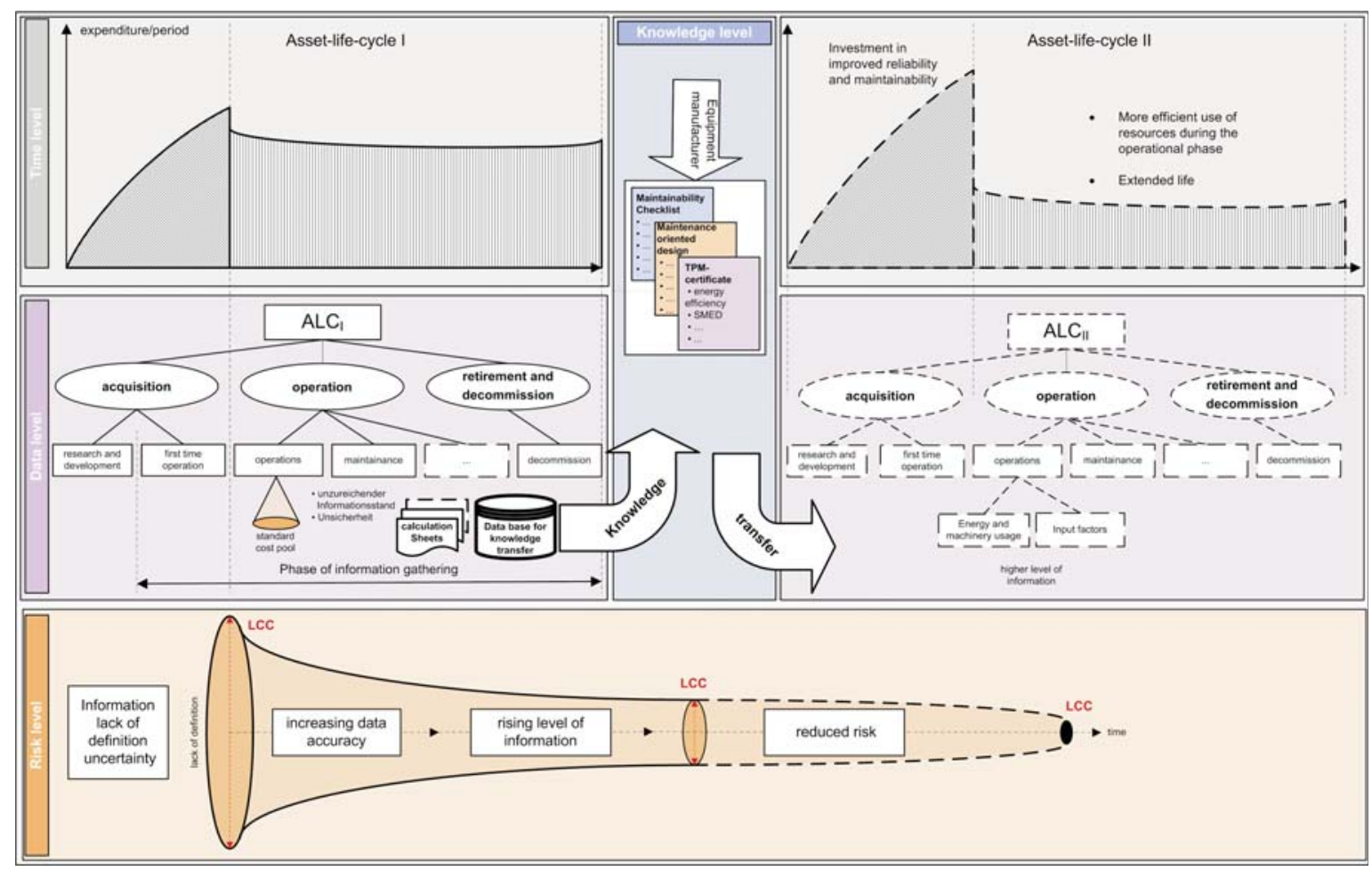

Figure 4. Concept of the life cycle cost tool 
The main criticisms are lack of reliability and validity, the lack of detail and the lack of expandability. In this paper a general model is deducted from existing approaches and the determined costs are evaluated with respect to priority and practical relevance. The result of the evaluation shows which costs are taken into account for investment decisions. Another outcome is the verification of importance of the proposed costs for industrial companies, especially for the process industry. The derived life cycle cost framework is the basis for developing a calculation tool and subsequently, for further research in the flied of uncertaintybased methodologies for life cycle cost analyzing of physical plant assets.
Acknowledgement: This paper is supported by the Austrian Scientific Maintenance and Asset Management Association (OEVIA). A special thank to all participating companies and members for their important contribution. Contact: www.oevia.at

\title{
ПРОЦЕНА ТРОШКОВА ЖИВОТНОГ ЦИКЛУСА ИМОВИНЕ ПРЕДУЗЕһА - ВИШЕДИМЕНЗИОНИ ПРИСТУП
}

\author{
Markus Gram* and Werner E. Schroeder
}

\begin{abstract}
Извод
Овај рад представља резултате радне групе "Управљање проценом животног циклуса" која ради под покровитељством Аустријске асоцијације за научни приступ одржавању и управљању поседом компаније (ÖVIA). Један од циљева истраживања је у стварању генеричког модела животног циклуса физичких добара који укључује све трошкове у свим фазама животног циклуса. Први корак се састојао у прегледу литературе у цињу утврђивања најпогоднијих модела трошкова животног циклуса. Ово је полазно становиште за даљу дискусију комплетности таквог оквира и примене у индустријским компанијама које учествују у овом истраживању. Општи модел је резултовао из постојећих приступа и одређени трошкови су процењивани уз поштовање приоритета и практичног значаја. Резултати процене показују који су трошкови од утицаја за одлучивање о инвестирању. Други ицход студије је верификација значаја предложених трошкова за индустријске компаније, посебно у процесној индустрији. Развијени оквир трошкова животног циклуса је основ за развој алата за калкулацију и потом, за даље истраживање на пољу методологије неизвесности трошкова животног циклуса и анализе физичких добара компанија.
\end{abstract}

Кључне речи: Трошкови животног циклуса, Одржавање, Управљање добрима, Процена трошкова, Одлуке о инвестирању 


\section{References}

Ahuja, I.P.S., \& Khamba, J.S. (2008). Total productive maintenance: literature review and directions. International Journal of Quality and Reliability Management, 25(7): 709756.

AmadiEchendu, J.E. (2004). The paradigm shift from maintenance to physical asset management. IEEE Transactions on Engineering Management (in press).

Barringer, H.P. (1997). Life cycle cost and reliability for process equipment. 8th Annual Energy Week Conference and Exhibition. Houston, Texas.

Campbell, J.D. (1995). Uptime: Strategies for Excellence in Maintenance Engineering. New York, NY, USA: Productivity Press.

Campbell, J.D., \& Jardine, A.K.S. (2001). Maintenance Excellence: Optimizing Equipement Life Cycle Decisions. New York, Basel: Marcel Decker Verlag.

DIN 31051 (2011). Fundamentals of maintenance. German Institute for Standardization (DIN).

Gleissdörfer, K., Gleich, R., \& Wald, A. (2009). Potentials in standardization of lifecycle models of strategic cost management (German). ZfB, 79: 693716.

IEC 6030033:2004. Dependability management Part 33: Application guide, Life cycle costing. German version EN 6030033:2004.

Kaufmann, R.J. (1969). Life Cycle Costing: Decision Making Tool For Capital Equipment Acquisition. Journal of Purchasing. August, 1631.

Kemminer, J. (1999). Life Cycle Orientated Cost and Revenue Management (German). Wiesbaden: Gabler Verlag.

Männel, W. (1988) Integrated maintenance management (German). Köln: TÜV Rheinland.
Mitchell, J.S., \& Carlson, J. (2001) Equipment asset management what are the real requirements. Reliability Magazine, October: 414.

Nebl, T., \& Prüß, H. (2005). Plant Asset Management (German). München, Wien: Oldenbourg.

North American Association of Food Equipment Manufacturers (NAFEM) (2006). LCC Model. Full Version 1. Chicago: NAFEM.

Riezler, S. (1996). Life Cycle Costing: Instrument of Controlling Strategic Projects (German). Wiesbaden: Gabler Verlag.

Selvik, J.T., \& Aven, T. (2011). A framework for reliability and risk centered maintenance. Reliability Engineering and System Safety, 96(2011): 324331.

Schuman, C.A., \& Brent, A.C. (2005). Asset life cycle management: towards improving physical asset performance in the process industry. International Journal of Operations \& Production Management, 25(6): 566579.

UNIFE (1997). Guidelines for Life Cycle Cost.

VDI (2008). Procurement, operation and maintenance of production equipment using LCC. Association of German Engineers (VDI).

VDMA 34160 (2007). Forecasting model for life cycle costs of machines and plants. German Engineering Federation (VDMA).

VDV 2315 (2010). Life Cycle Costs (LCC) for LineService Buses Evaluation Criteria for Tenders. Köln, VDVReports, Vehicles, Buses/Commercial Vehicles.

Waeyenberg, G., \& Pintelon, L. (2002). A framework for maintenance concept development. International Journal of Poduction Economics, 77(3): 299313.

Zehbold, C. (1996). Life Cycle Costing (German), Wiesbaden: Gabler Verlag. 